\title{
EKSTRAKURIKULER TAEKWONDO DALAM MENGEMBANGKAN KARAKTER KERJA KERAS
}

\author{
Devi Listya Wardani \\ Universitas PGRI Semarang \\ listyawardani20@gmail.com
}

\author{
Ratna Wahyu Pusari \\ Universitas PGRI Semarang \\ Ratna12@gmail.com
}

Husni Wakhyudin

Universitas PGRI Semarang Husni55@gmail.com

\begin{abstract}
Abstrak
Penelitian ini membahas bagaimana kegiatan ekstrakurikuler taekwondo dalam mengembangkan karakter kerja keras siswa. Tujuannya untuk mengetahui kegiatan ekstrakurikuler taekwondo dalam mengembangkan karakter kerja keras siswa. Penelitian ini menggunkakan pendekatan deskriptif kualitatif dengan mengambil data sesuai dengan fakta dilapangan. Data diperoleh dianalisis dan disajikan dalam bentuk deskriptif. Dari penelitian ini menunjukkan bahwa kegiatan ekstrakurikuler taekwondo di SD Negeri Candi 01 Semarang dapat mengembangkan karakter kerja keras siswa dengan baik. Karakter kerja keras tersebut diantaranya yaitu siswa bersungguh-sungguh saat pelatih memberikan materi taekwondo, siswa selalu bersemangat dalam mengerjakan tugasnya, siswa selalu bekerja keras agar mendapatkan tingkatan sabuk yang lebih tinggi. Siswa selalu mendengarkan dengan sungguh-sungguh ketika pelatih menerangkan materi. Siswa tidak mengeluh ketika ada gerakan/teknik taekwondo yang susah saat diajarkan pelatih dan siswa selalu berusaha menyelesaikan tugas dari pelatih dengan tuntas.
\end{abstract}

Kata Kunci : Ekstrakurikuler, Taekwondo, Karakter Kerja Keras

\begin{abstract}
Abstrac
This study discusses how taekwondo extracurricular activities in developing students' hard work character. The aim is to find out the taekwondo extracurricular activities in developing the character of students' hard work. This study uses a qualitative descriptive approach by taking data in accordance with the facts in the field. Data obtained were analyzed and presented in descriptive form. From this research it shows that the extracurricular activities of taekwondo in Candi 01 Semarang State Elementary School can develop the character of students' hard work well. The character of the hard work includes students being serious when the trainer gives taekwondo material, students are always enthusiastic in doing their work, students always work hard in order to get a higher belt level. Students always listen intently when the trainer explains the material. Students do not complain when there are movements / techniques of taekwondo that are difficult when taught by the trainer and students always try to complete the tasks of the trainer completely.
\end{abstract}

Keywords: Extracurricular, Taekwondo, Hard Work Character

\section{Pendahuluan}

Pendidikan merupakan proses kehidupan setiap individu untuk mengembangkan potensi yang dimilikinya untuk menjadikan individu yang cerdas dan bermoral. Potensi yang dikembangkan ialah kemampuan, pengetahuam keterampilan, dan membentuk watak, karakter, kepribadian seseorang yang berakhlak, berilmu, kreatif, mandiri dan bertanggungjawab. Sekolah merupakan suatu lembaga pendidikan yang memberikan wadah kepada peserta didik, yang nantinya akan dibina dan dididik agar bisa menjadi manusia yang memiliki pengetahuan, keterampilan, dan menjadi manusia yang berakhlak mulia.

Pendidikan menurut G. Thompson dalam Mikarsa (2012: 3) menyatakan bahwa pendidikan adalah pengaruh lingkungan atas individu untuk menghasilkan perubahan-perubahan yang tetap di dalam kebiasaankebiasaan, pemikiran, sikap-sikap, dan tingkah laku. Fungsi utama dalam pendidikan adalah bimbingan terhadap individu dalam upaya memenuhi kebutuhan dan keinginan sesuai dengan potensi yang dimilikinya sehingga dia memperoleh kepuasan dalam seluruh aspek kehidupan pribadi dan kehidupan sosialnya (Crow and Crow dalam Mikarsa, 2012: 3)

Dalam pasal 3 Undang-Undang Nomor 20 Tahun 2003 menyebutkan bahwa: 
"Pendidikan nasional berfungi mengembangkan kemampuan dan membentuk watak serta peradaban bangsa yang bermartabat dalam rangka mencerdaskan kehidupan bangsa, bertujuan untuk berkembangnya potensi peserta didik agar menjadi manusia yang beriman dan bertakwa kepada Tuhan Yang Maha Esa, berakhlak mulia, sehat, berilmu, cakap, kreatif, mandiri, dan menjadi warga negara yang dremokatis serta bertanggungjawab".

Mangacu pada tujuan pendidikan tersebut manusia dituntut untuk saling berkompetisi membentuk karakter menonjol melalui pengetahuan, sikap, dan ketrampilan. Dengan kata lain, pendidikan merupakan upaya untuk membentuk karakter kuat dan baik sehingga terbentuk perwujudan kesatuan perilaku dan sikap hidup peserta didik. Pendidikan karakter perlu ditekankan karena sebagai pembentuk budi pekerti yang baik sejak dini. Dalam pendidikan karakter sangat penting dikembangkan nilai-nilai inti seperti kepedulian, kejujuran, keadilan, tanggungjawab, dan rasa hormat terhadap diri dan orang lain bersama dengan nilai-nilai kinerja pendukungnya seperti ketekunan, etos kerja yang tinggi, dan kegigihan sebagai basis karakter yang baik, Muslich (2011: 129).

Pendidikan karakter merupakan pendidikan nilai, pendidikan budi pekerti, pendidikan moral, pendidikan watak yang bertujuan mengembangkan kemampuan siswa untuk memberikan keputusan baik-buruk memelihara apa yang baik dan mewujudkan kebaikan itu dalam kehidupan sehari-hari dengan sepenuh hati (Kementrian Pendidikan Nasional dalam Saripudin, 2017: 16). Keluarga merupakan tempat pertama memulai penanaman sekaligus mengembangkan karakter anak. Orang tua sangat berperan penting dalam mengembangkan karakter anak, selain orang tua ada lembaga pendidikan yaitu sekolah, sebagai pihak kedua dalam mananamkan dan mengembangkan karater yang baik untuk anak. Tujuan pendidikan karakter adalah memfasilitasi penguatan dan pengembangan nilai-nilai tertentu sehingga terwujud dalam perilaku anak, baik ketika proses sekolah maupun setelah proses sekolah (setelah lulus dari sekolah), Muhammad Najib (2016: 69).

Terdapat banyak sekali nilai-nilai karakter yang perlu dikembangkan pada anak, salah satunya yakni pendidikan karakter kerja keras. Kerja keras menurut Gunawan (2015: 143) merupakan perilaku yang menunjukkan upaya sungguh-sungguh dalam mengatasi berbagai hambatan belajar, tugas dan menyelesaikan tugas dengan sebaik-baiknya.Dengan mengembangkan karakter kerja keras, anak diharapkan mampu bersungguh-sungguh dalam mengerjakan sesuatu agar mendapatkan hasil yang maksimal. Saat ini upaya yang dinilai baik untuk mengembangkan karakter anak agar tersampaikan dengan baik yaitu sekolah. Salah satu wadah yang berpotensi mengembangkan karakter kerja keras yaitu melalui ekstrakurikuler taekwondo yang saat ini ada di SD N Candi 01. Hal ini dilakukan untuk memperbaiki rendahnya pendidikan karakter kerja keras yang masih saja menjadi permasalahan di era globalisasi saat ini.

Rendahnya karakter kerja keras sering ditemui dilingkungan sekolah, sebagai contohnya rendahnya karakter kerja yaitu siswa tidak bersemangat dalam mengikuti pembelajaran, siswa tidak bersungguh-sungguh dalam menyelesaikan tugasnya, siswa tidak percaya diri terhadap apa yang ia kerjakan, dan siswa tidak berani tampil di depan umum. Indikator kerja keras menurut Wibowo (2015: 144) diantaranya: (1) Menciptakan suasana kompetisi yang sehat. (2) Menciptakan suasana sekolah yang menantang dan memacu untuk bekerja keras. (3) Memiliki pajangan tentang slogan atau motto tentang kerja keras. Dengan kegiatan ekstrakurikuler taekwondo ini mampu mengembangkan karakter kerja keras siswa yang berkompetisi secara sehat bersemangat dalam bekerja atau menyelesaikan tugasnya, dan menciptakan suasana sekolah yang menantang seperti berani tampil di depan umum.

Kegiatan ekstrakurikuler merupakan kegiatan yang dilaksanakan pada jam di luar pembelajaran yang berisi kegiatan mengembangkan bakat dan minat peserta didik dengan tujuan untuk menggali dan mengasah potensi yang sesuai dengan bakat yang dimiliki setiap peserta didik. Sedangkan ekstrakurikuler menurut Andriani (2015: 2) adalah kegiatan yang dilakukan di luar jam sekolah yang berfungsi untuk mewadahi dan mengembangkan potensi, minat dan bakat siswa. Selain itu, kegiatan ekstrakurikuler diartikan sebagai pendidikan di luar mata pelajaran dan pelayanan konseling untuk membantu pengembangan peserta didik sesuai dengan kebutuhan, potensi, bakat, dan minat melalui kegiatan secara khusus diselenggarakan oleh pendidik dan atau tenaga kependidikan yang berkemampuan dan berkewenangan di sekolah/madrasah.

Taekwondo menurut Suryadi (2002: 1) merupakan seni atau cara mendisiplinkan diri atau seni bela diri yang menggunakan teknik kaki dan tangan kosong. Taekwondo merupakan ilmu seni bela diri yang memiliki berbagai nilai-nilai yang terkandung didalammya seperti sikap peduli sosial, kerja keras, disiplin, toleransi dan rasa percaya diri. Dengan adanya kegiatan ekstrakurikuler taekwondo tersebut diharapkan nantinya dapat mengebangkan karakter kerja keras siswa.

Berdasarkan latar belakang diatas, maka peneliti tertarik untuk mengadakan penelitian berjudul "Ekstrakurikuler Taekwondo Dalam Mengembangkan Karakter Kerja Keras Siswa SD Negeri Candi 01 Semarang. Dalam penelitian ini peneliti ingin mengetahui seberapa besar pengembangan karakter kerja keras melalui kegiatan ekstrakurikuler taekwondo di SD Negeri Candi 01 Semarang serta mengetahui bentuk kegiatan ekstrakurikuler taekwondo dalam mengembangkan karakter kerja keras di SD Negeri Candi 01 Semarang, dan mengetahui faktor pendorong dan penghambat dalam mengembangkan karakter kerja keras melalui kegiatan ekstrakurikuker taekwondo di SD Negeri Candi 01 Semarang. 


\section{Metode}

Penelitian ini menggunakan pendekatan kualitatif yaitu penelitian yang bersifat deskriptif. Penelitian deskriptif kualitatif ini mengacu pada Arikunto (2010: 21) yaitu data yang diwujudkan dalam kata keadaan atau kata sifat. Pada penelitian ini data yang diperoleh merupakan data atau informasi yang sesuai dengan kenyataan dilapangan. Dan diolah dengan pendekatan deskriptif kualitatif yang akan disimpulkan mengenai bagaimana peran ekstrakurikuler taekwondo dalam mengembangkan karakter kerja keras siswa.

\section{Hasil dan Pembahasan}

Ekstrakurikuler taekwondo di SD Negeri Candi 01 Semarang diadakan pada hari kamis pukul 13.00 15.00. Ekstrakurikuler taekwondo diampu oleh Oky Aditya Tri Nugroho sejak bulan Agustus 2018 yang merupakan lulusan pelajar dari SMK Pelayaran Semarang. Kegiatan ekstrakurikuler taekwondo di SD Negeri Candi 01 Semarang merupakan salah satu contoh kegiatan ekstrakurikuler yang dapat digunakan untuk mengembangkan karakter kepada siswanya. Salah satu contoh nilai karakter yang dapat dikembangkan adalah nilai karakter kerja keras.

Peneliti memilih SD Candi 01 Semarang karena sekolah tersebut merupakan sekolah yang digunakan magang oleh peneliti dan terdapat kegiatan ekstrakurikuler taekwondo yang mampu mengembangkan bakat serta minat siswa. Selain mampu mengembangkan bakat serta minat siswa kegiatan taekwondo ini juga mampu mengembangkan karakter kerja keras siswa seperti mendorong siswa untuk mengembangkan semangat kerja keras dalam menyelesaikan suatu tugasnya. Kemudian pelatih juga mengajarkan siswa untuk bersungguhsungguh dalam menirukan gerakan yang di ajarkan oleh pelatih, tidak bermalas-malasan, dan berusaha dengan keras untuk berlatih gerakan baru yang di ajarkan pelatih.

Berdasarkan deskripsi dan penemuan, pembahasan dalam penelitian ini adalah ekstrakurikuler taekwondo dalam mengembangkan karakter kerja keras siswa SD Negeri Candi 01 Semarang.

Menurut Andriani (2015: 2) ekstrakurikuler adalah kegiatan yang dilakukan di luar jam sekolah yang berfungsi untuk mewadahi dan mengembangkan potensi, minat dan bakat siswa. Hasil wawancara dengan pelatih ekstrakurikuler taekwondo Oky Aditya Tri Nugroho di SD Candi 01 Semarang selain untuk mengembangkan potensi, bakat dan minat siswa juga memiliki tujuan lain yaitu mengembangkan karakter kerja keras siswa. Dalam hal ini yang dimaksud adalah siswa-siswi SD Candi 01 Semarang yang mengikuti kegiatan ekstrakurikuler taekwondo. Karakter kerja keras siswa dapat dikembangkan apabila sungguh-sungguh dalam mengikuti kegiatan ekstrakurikuler taekwondo. Sesuai dengan pernyataan Oky Aditya Tri Nugroho "ya dengan mengembangkan karakter kerja keras tentu ada tujuannya yaitu siswa bisa bekerja mandiri, berlatih disiplin, bekerja keras jika ingin mendapat tingkat suatu sabuk yang lebih tinggi, tidak bermalas-malasan, beralatih dengan giat, dan selalu bersungguh-sungguh saat pelatih memberikan materi atau teknik taekwondo".

Kementrian Pendidikan Nasional dalam Saripudin (2017: 16) menjelaskan bahwa pendidikan karakter merupakan pendidikan nilai, pendidikan budi pekerti, pendidikan moral, pendidikan watak yang bertujuan mengembangkan kemampuan siswa untuk memberikan keputusan baik-buruk memelihara apa yang baik dan mewujudkan kebaikan itu dalam kehidupan sehari-hari dengan sepenuh hati. Artinya, pendidikan karakter merupakan upaya sadar seseorang untuk mengembangkan karakter baik buruknya seseorang dikehidupan sehariharinya. Diperkuat dengan wawancara dengan Ibu Wartini selaku Kepala Sekolah SD Negeri Candi 01 Semarang menjelaskan bahwa pendidikan karakter merupakan pendidikan moral baik buruknya karakter pada anak yang harus dikembangkan dengan baik. Pendidikan karakter pada anak itu sangat di pentingkan terutama di SD Negeri Candi 01 karena selain anak berpengetahuan yang luas anak juga harus berkarakter, karena sangat penting didalamnya untuk mengembangkan karakter pada anak diantaranya karakter religius, disiplin, nasionalis, gotong royong, mandiri, kerja keras, dan integritas maka akan tertanam ke dalam hatinya anak sifat-sifat karakter tersebut. Apalagi saat ini kurikulum 2013 gencar menanamkan penguatan pendidikan karakter pada anak. Di SD Candi 01 juga ada beberapa ekstrakurikuler yang tujuannya mengembangkan pendidikan karakter pada anak salah satunya yaitu ekstrakurikuler taekwondo yang dapat mengembangkan karakter anak agar mandiri, religius, disiplin, nasionalis, gotong royong, dan pastinya berkarakter kerja keras.

Dari penjelasan diatas dapat disimpulkan bahwa pendidikan karakter sangat penting untuk diterapkan pada siswa. Dengan melalui ektrakurikuler taekwondo di SD Negeri Candi 01 Semarang siswa dapat menembangkan potensi, bakat dan minat siswa. Selain itu ekstrakurikuler taekwondo di SD Negeri Candi 01 juga dapat mengebangkan karakter kerja keras siswa. Seperti halnya siswa harus berusaha dengan keras saat ingin mendapatkan suatu tingkat sabuk yang lebih tinggi, siswa juga harus bersungguh-sungguh dalam mempelajari teknik taekwondo yang diajarkan pelatih dan siswa juga harus belajar dengan giat saat mendapatkan teknik taekwondo yang baru diajarkan pelatih.

Kerja keras menurut Gunawan (2015: 143) merupakan perilaku yang menunjukkan upaya sungguhsungguh dalam mengatasi berbagai hambatan belajar, tugas dan menyelesaikan tugas dengan sebaik-baiknya. Ciri dari kerja keras adalah tekun dan ulet, teliti dan cermat, menghargai waktu dan bekerja keras, bekerja cerdas, disiplin, sabar, ikhlas, dan pantang menyerah (Angelica dalam Nita (2014: 31). Dalam mengembangkan 
karakter kerja keras yang dilaksanakan melalui kegiatan ekstrakurikuler taekwondo di SD Negeri Candi 01 Semarang dapat memberikan dampak positif bagi sikap atau perilaku siswa. Siswa yang awalnya bermalasmalasan sekarang sudah bersungguh-sungguh saat pelatih memberikan materi taekwondo, siswa selalu bersemangat dalam mengerjakan tugasnya, siswa selalu bekerja keras agar mendapatkan tingkatan sabuk yang lebih tinggi. Siswa selalu mendengarkan dengan sungguh-sungguh ketika pelatih menerangkan materi siswa selalu bertanya apabila ada gerakan/teknik yang susah. Siswa sering mengulang gerakan yang sudah diajarkan ketika jam istirahat. Siswa tidak mengeluh ketika ada gerakan/teknik yang susah saat diajarkan pelatih dan siswa selalu berusaha menyelesaikan tugas dari pelatih dengan tuntas.

Bukti-bukti penemuan penelitian diatas diperkuat dengan angket siswa dari 35 responden yang memperkuat jawaban dari fokus penelitian yaitu bagaimana ekstrakurikuler taekwondo dalam mengembangkan karakter kerja keras siswa. Hasil yang didapatkan dari angket siswa yakni siswa sudah mengembangkan karakter kerja keras dengan baik melalui kegiatan ekstrakurikuler taekwondo, hasil angket ini memperkuat hasil temuan wawancara dan observasi sebelumnya.

Pelaksanaan kegiatan ekstrakurikuler tekwondo dalam mengembangkan karakter kerja keras siswa sudah baik. Sesuai dengan pernyataan Oky Aditya Tri Nugroho pelatih ekstrakurikuler taekwondo "ekstrakurikuler taekwondo dalam mengembangkan karakter kerja keras siswa sudah baik, siswa yang awalnya belum tertib mengikuti kegiatan ekstrakurikuler taekwondo sekarang sudah mulai tertib. Awalnya siswa susah di atur saat kegiatan berlangsung tapi lama kelamaan sudah mulai terbiasa menerima materi dengan baik. Siswa sudah bersungguh-sungguh menirukan teknik-teknik yang sudah diajarkan. Siswa juga giat belajar teknik-teknik yang baru diajarkan. Kemudian juga anak sangat bersemangat berlatih, giat belajar, dan pantang menyerah meningkatkan tingkatan suatu sabuk dan saat akan mengikuti perlombaan mewakili sekolah.”

Dari penjelasan diatas dapat di simpulkan bahwa kegiatan ekstrakurikuler taekwondo dalam mengembangkan karakter kerja keras siswa SD Negeri Candi 01 sudah baik. Siwa bersungguh-sungguh saat pelatih memberikan materi taekwondo, siswa selalu bersemangat dalam mengerjakan tugasnya, siswa selalu bekerja keras agar mendapatkan tingkatan sabuk yang lebih tinggi. Siswa selalu mendengarkan dengan sungguhsungguh ketika pelatih menerangkan materi siswa selalu bertanya apabila ada gerakan/teknik yang susah. Siswa sering mengulang gerakan yang sudah diajarkan ketika jam istirahat. Siswa tidak mengeluh ketika ada gerakan/teknik yang susah saat diajarkan pelatih dan siswa selalu berusaha menyelesaikan tugas dari pelatih dengan tuntas. Hal ini sesuai dengan penjelasan indikator Abu Su'ud (2011: 58) menjelaskan bahwa indikator kelas kerja keras diantaranya: (1) Menciptakan suasana kompetisi yang sehat. (2) Menciptakan kondisi etos kerja, pantang menyerah, dan daya tahan belajar. (3) Menciptakan suasana belajar yang memacu daya tahan kerja.

\section{Simpulan dan saran}

Berdasarkan temuan penelitian dan pembahasan, maka dapat disimpulkan bahwa kegiatan ekstrakurikuler taekwondo di SD Negeri Candi 01 Semarang dapat mengembangkan karakter kerja keras siswa dengan baik. Karakter kerja keras tersebut diantaranya yaitu siswa bersungguh-sungguh saat pelatih memberikan materi taekwondo, siswa selalu bersemangat dalam mengerjakan tugasnya, siswa selalu bekerja keras agar mendapatkan tingkatan sabuk yang lebih tinggi. Siswa selalu mendengarkan dengan sungguh-sungguh ketika pelatih menerangkan materi. Siswa tidak mengeluh ketika ada gerakan/teknik taekwondo yang susah saat diajarkan pelatih dan siswa selalu berusaha menyelesaikan tugas dari pelatih dengan tuntas.

Saran yang berkaitan dengan penelitian ini yaitu untuk memberikan inovasi baru dalam kegiatan ekstrakurikuler. Misalnya dengan melibatkan siswa dalam sebuah pertandingan yang diadakan di SD sendiri dan memberikan apresiasi pada siswa yang menang. Pertandingan tidak hanya dilakukan saat perlombaan mewakili sekolah. Dengan hal tersebut dapat menambah ketertarikan siswa mengikuti serangkaian pelaksanaan ekstrakurikuler taekwondo dan menambah kerja keras siswa untuk berlatih setiap teknik taekwondo yang sudah diajarkan.

\section{Daftar Pustaka}

Abu Su'ud, S. d. (2011). Pendidikan Karakter. Semarang: IKIP PGRI Semarang Press. Andriani, Y. A. (2015). Pengembangan Ekstrakurikuler Olahraga Sekolah. Yogyakarta: UNY Press. Arikunto, S. (2010). Prosedur Penelitian Suatu Pendekatan Praktik. Jakarta : Rineka Cipta. Arikunto, S (2013). Prosedur Penelitian Suatu Pendekatan Praktik. Jakarta: Rineka Cipta.

Asep Herry Hernawan, d. (2013). Pengembangan Kurikulum dan Pembelajaran. Tangerang Selatan: Universitas Terbuka.

Daryanto, H. (2013). Administrasi dan Manajemen Sekolah. Jakarta: Rineka Cipta.

Derwanto, N. A. (2015). Kebugaran Jasmani Siswa Ekstrakurikuler Bela Diri Taekwondo Di SDIT Mutiara Insani Jeronan Brosot Galur Kulon Progo.Universitas Negeri Yogyakarta. 
Gunawan, A. W. (2015). Pendidikan Karakter Berbasis Kearifan Lokal Di Sekolah. Yogyakarta: Pustaka Pelajar.

Handayani, Nita Warih dan Sumaryati. (2014). Upaya Orang Tua dalam Menanamkan Karakter Kerja Keras Anak Usia Remaja di Dusun Tegalyoso Banyuraden Sleman Yogyakarta. http://www.journal.uad.ac.id/index.php/Citizenship/article/view/6280. Artikel. Diakses 8 Mei 2019.

Ihsan, F. (2013). Dasar-Dasar Kependidikan. Jakarta: Rineka Cipta.

Irhas, E. (2010). Panduan Lengkap Belajar Taekwondo. Bogor: PT. Regina Eka Utama.

Izzati, S. N. (2016). Survei Pembinaan Ekstrakurikuler Olahraga Taekwondo Di SMP N Di Kabupaten Brebes Tahun 2016. HYPERLINK "https://lib.unnes.ac.id/27021/1/6101412154.pdf" https://lib.unnes.ac.id/27021/1/6101412154.pdf . Skripsi. Di Akses 6 Oktober 2019.

Kesuma, D. (2012). Pendidikan Karakter Kerja Teori dan Praktik di Sekolah . Bandung: PT Remaja Rosdakarya.

Moleong, L. J. (2008). Metodologi Penelitian Kualitatif. Bandung: Remaja Rosdakarya.

Maulana, I. (2017). Motivasi Siswa Dalam Mengikuti Kegiatan Ekstrakurikuler Taekwondo Di SMKN 1 Banda Aceh Tahun Ajaran 2016/2017

"http://etd.unsyiah.ac.id/index.php?p=show_detail\&id=37952"

http://etd.unsyiah.ac.id/index.php?p=show_detail\&id=37952 . Skripsi. Diakses 8 Mei 2019.

Muhammad Najib, N. A. (2016). Strategik Pendidikan Karakter Bagi Anak Usia dini. Yogyakarta: Penerbit Gava Media.

Mulyasa, H. (2011). Manajemen Pendidikan Karakter. Jakarta : PT Bumi Aksara.

Muslich, M. (2011). Pendidikan karakter Menjawab Tantangan Krisis Multidimensional. Jakarta: Bumi Aksara.

Rahmani, M. (2014). Buku Super Lengkap Olahraga. Jakarta Timur: Dunia Cerdas.

Rubiningsih, E. (2016). Efektivitas Implementasi Pendidikan Karakter kerja Keras Berbasis Layanan Bimbingan Klasikal Kolaboratif Dengan Pendekatan Experiental learning. https://repository.usd.ac.id/6588/2/121114018_full.pdf. Skripsi. Diakses 8 Mei 2018.

Saripudin, K. K. (2017). Pendidikan Karakter. Bandung: PT Refika Aditama.

Siswanto, H. (2018). Implementasi Ekstrakurikuler Taekwondo di Madrasah Ibtidaiyah Al-Falah Gedongan Sukoharjo. HYPERLINK "http://eprints.ums.ac.id/66506/11/Heri.pdf" http://eprints.ums.ac.id/66506/11/Heri.pdf . Skripsi. Diakses 8 Mei 2019.

Sugiyono. (2016). Metode Penelitian Kuantitatif, Kualitatif, dan R\&D. Bandung: Alfabeta.

Sukmadinata, N. S. (2016). Metode Penelitian Pendidikan. Bandung: PT Rosdakarya.

Suryadi, V. Y. (2002). Tae Kwon Do. Jakarta: PT Gramedia Pustaka Utama.

Suryosubroto, B. (2009). Proses Belajar Mengajar di Sekolah . Jakarta: Rineka Cipta.

Wiyani, N. A. (2012). Manajemen Pendidikan karakter. Depok: PT Pustaka Insan Madani.

Yaumi, M. (2014). Pendidikan karakter Berbasis Kearifan Lokal Di Sekolah. Jakarta: Prenadamedia Grub. 